ESTUDIOS SOBRE LA ECONOMÍA ESPAÑOLA

Evolving Federations and Regional Public Deficits:

Testing the Bailout Hypothesis in the Spanish Case

Santiago Lago-Peñas

EEE 193

October 2004

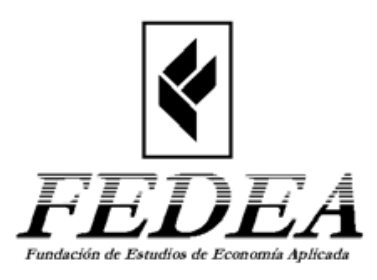

http://www.fedea.es/hojas/publicado.html

ISSN $1696-6384$

Las opiniones contenidas en los Documentos de la Serie EEE, reflejan exclusivamente las de los autores y no necesariamente las de FEDEA.

The opinions in the EEE Series are the responsibility of the authors an therefore, do not necessarily coincide with those of the FEDEA. 


\title{
EVOLVING FEDERATIONS AND REGIONAL PUBLIC DEFICITS: TESTING THE BAILOUT HYPOTHESIS IN THE SPANISH CASE ${ }^{1}$
}

\begin{abstract}
:
High debt autonomy and low tax autonomy often characterize evolving federations, making the bailout hypothesis very attractive when explaining subcentral governments deficits. However, meeting both conditions is not enough to conclude that bailout expectations are the main explanation for potential deficit. There are many other factors affecting expectations and real behavior of involved agents: central government, subcentral governments, and financial markets. Empirical research is then the only way to determine the relevance of the bailout problem in each situation. To show this argument, an exhaustive analysis of the Spanish case is carried on in this paper. The main conclusion is that deficit seems to be better understood by a more traditional model of fiscal choices than by bailout expectations.
\end{abstract}

KEYWORDS: Public deficit, public debt, bailout, evolving federations, Spain

JEL CODE: $\mathrm{H} 74$

Santiago Lago-Peñas

Departament of Applied Economics

University of Vigo

ADDRESS:

Facultade de Ciencias Empresariais

Campus universitario

32004 Ourense

SPAIN

E-mail: slagop@uvigo.es

April 2004

\footnotetext{
${ }^{1}$ Financial support by the Instituto de Estudios Fiscales (www.ief.es) is acknowledged. I have received very helpful comments from Alex Esteller, Timothy Goodspeed, Ignacio Lago-Peñas, Thierry Madiès, Diego Martínez, Joan Rosselló, Albert Solé-Ollé, and participants to the XI Encuentro de Economía Pública (Barcelona, 2004). Usual disclaimer applies.
} 


\section{MOTIVATION}

Influenced by the new theory of the firm and concerned with incentive problems, recent contributions to the theory of fiscal federalism have imported both concepts of "soft budget constraint" and "bailout" to intergovernmental relations (Quian and Weingast, 1998) ${ }^{2}$. This operation is developed in papers by Wildasin (1997), Qian and Roland (1998), García-Milá et al (2002), Goodspeed (2002), and Cooper et al (2004), among others. One of the most relevant results from this expanding literature is the finding of an additional determinant of subcentral public deficits, to be taken into account in empirical studies: Ceteris paribus, governments expecting to be bailed out from financial problems will opt for larger deficits.

Several conditions boosting bailout expectations have been identified in the literature; mainly, high subcentral debt autonomy and low subcentral tax autonomy. However, meeting both conditions is not enough to conclude that bailout expectations are the main explanation for potential deficit. As it will be shown, there are many other factors affecting expectations and real behavior of involved agents: central government, subcentral governments, and financial markets. Empirical research is then the only way of testing the relevance of the bailout problem in each situation.

To show this argument, an exhaustive analysis of the Spanish case is carried on in this paper. Spain is a good example of evolving federation with high subcentral debt autonomy and low tax autonomy. Moreover, the debt of Spanish regional governments rose sharply in the late eighties and the first half of the nineties. Could bailout expectations convincingly explain this behavior? Although this question has been previously addressed by García-Milá et al (2002), they just test some of the empirical relationships between observable variables potentially activated by bailout expectations.

The article is organized in five sections, including this introduction. In section two, literature on bailouts in evolving federations is surveyed. The aim is twofold. Firstly, to discuss the conditions which could boost bailout expectations. Secondly, to summarize the empirical implications of bailout models and results found in the

\footnotetext{
${ }^{2}$ Seminal paper by Kornai (1986) explicitly rejected the application of the concept of "soft budget constraint" to the public sector.
} 
literature. In section three an overview on fiscal federalism in Spain is presented. In section four an empirical analysis of the Spanish case is carried on. Section five concludes.

\section{RELATED LITERATURE}

First of all, let us differentiate between "soft budget constraint" and "bailout". One region may expect an increase in granted revenues in the future because for more reasons than bailout expectations. For instance, equalization systems use to be revised periodically, suggesting the possibility of altering the distribution and total amount of equalization grants. This would be an example of soft budget constraint, defined as: "the situation when an entity (say, a province) can manipulate its access to funds in undesirable ways" (Rodden et. al, 2003, p.7). Hence, the inability of the rescuer to generate expectations of no bailout entails a soft budget constraint, but there are other mechanisms to soften a budget constraint (Inman, 2003).

The mere existence of limits on borrowing does not guarantee expectations of no bailout. Firstly, because they may be soft. Depending on the way they are defined, regions may find subtle channels for circumventing limits and hiding deficit (McCarten, 2003; Rodden and Eskeland 2003). Secondly, high limits do not avoid an accumulation of a significant stock of debt. Thirdly, bailout expectations depend on more factors. One of then would be tax decentralization: The higher the tax autonomy the lower the risk of a bailout (Rodden, 2002). Using cross-country data, Eichengreen and Von Hagen (1996) show that the probability of imposing credit constraints increases with the vertical fiscal imbalance size because the only choices left to a central government will be to allow a subcentral government to go into bankruptcy or to bail it out. Von Hagen et al (2000) clarify that no tax autonomy and vertical fiscal imbalance are not the same. In their opinion, the former is the most relevant when talking about bailouts. All in all, as Pisauro (2001) states, this reasoning overlooks the moral hazard problem. If subcentral governments expect to be bailed out by central government, they will then have no incentives to use their fiscal autonomy.

Interdependence between central and subcentral tiers could be also relevant to the bailout problem. According to Rodden et al (2003, p.11): "If a local government is 
merely a branch of the central government, then punishing its citizens is useless at best. It is only as the municipality becomes a body on its own, a creature of its own citizens with powers to match its responsibilities, that the central government might credibly commit to let it face the consequences of its actions". On the contrary, if subcentral governments are too strong, the central government might appear to be little more than a loose coalition of logrolling regional interest groups. Hence, extremely dependent subcentral governments from the central one or subcentral governments capable of influencing on national politics would rise the probability of bailouts. In a similar way, Burki et al (1999) posit that the political ability of central government to enforce hard budget constraints is positively correlated to the strength and discipline of state-wide political parties. Conversely, strong regional parties could soften subcentral budget constraints by means of political pressures on the central government.

From the perspective of spending, Burki et al (1999) point out that spending autonomy increases the capacity of subcentral governments to stay within a budget constraint. Expectations of bailout will be higher if the central government constraints subcentral choices on spending. Moreover, Burki et al (1999) suggest that a firm allocation of spending responsibilities and the predominance of ruled-based grants will reduce expectations of bailouts.

Finally, bailout expectations may also depend on the capacity of a central government to force subnational governments to service their debts, enforcing losses on banks with bad loans to uncreditworthy subnational governments and maintaining central bank independence (Burki et al, 1999). Conditions boosting bailout expectations are listed in table 1. 
TABLE 1: CONDITIONS BOOSTING BAILOUT EXPECTATIONS

\begin{tabular}{|l||}
\hline $\begin{array}{l}\text { NO LIMITS ON BORROWING (OR HIGH AND SOFT LIMITS) } \\
\text { (McCarten, 2003; Rodden and Eskeland 2003) }\end{array}$ \\
\hline $\begin{array}{l}\text { NO TAX AUTONOMY } \\
\text { (Maskin, 1999; Rodden, 2002; Von Hagen et al, 2000; Eichengreen and Von Hagen, 1996) }\end{array}$ \\
\hline $\begin{array}{l}\text { NO SPENDING AUTONOMY } \\
\text { (Burki et al, 1999) }\end{array}$ \\
\hline $\begin{array}{l}\text { A FUZZY ALLOCATION OF SPENDING RESPONSIBILITIES } \\
\text { (Burki et al, 1999) }\end{array}$ \\
\hline $\begin{array}{l}\text { PREDOMINANCE OF NO RULE-BASED GRANTS } \\
\text { (Burki et al, 1999) }\end{array}$ \\
\hline $\begin{array}{l}\text { SUBCENTRAL GOVERNMENTS EXTREMELY STRONG OR TOO WEAK } \\
\text { (Rodden et al, 2003) }\end{array}$ \\
\hline $\begin{array}{l}\text { WEAK AND UNDISCIPLINED STATE POLITICAL PARTIES } \\
\text { (Burki et al, 1999) }\end{array}$ \\
\hline $\begin{array}{l}\text { STRONG REGIONAL PARTIES } \\
\text { (Rodden et al, 2003) }\end{array}$ \\
\hline $\begin{array}{l}\text { NO CLEAR COMMITMENTS ON PART OF THE CENTRAL GOVERNMENT ABOUT NO } \\
\text { BAILING OUT } \\
\text { (Burki et al, 1999) }\end{array}$ \\
\hline \hline
\end{tabular}

As it was pointed out in the introduction, meeting a number of conditions in table 1 is not a final demonstration of the existence of bailout expectations. An empirical analysis is needed to test the relevance of the bailout problem. At least, there are two ways of dealing with it. One of them is to look at the expectations of subnational governments directly. This is the way followed by Dahlberg and PetterssonLidbom (2003) and Bordignon and Turati (2003). The other - used in this paper- is based on the observation of the real behavior of subcentral governments, central government and financial markets. In other words, the focus of this approach is on connections among observable variables that bailout expectations should activate. While bailout models involve a number of testable relationships among observable variables, there are other possible explanations for subcentral deficit with different empirical implications. Therefore, it should not be difficult to ascertain the most reliable story in each case. In what follows, empirical implications of bailout models suggested in the literature are discussed.

In principle, generalized bailout expectations should foster deficit in all regions; or a similar exploitation of limits on debt and deficit if they exist. However, Wildasin (1997) shows that the probability of a region being bailed out increases with its economic size. The bigger a regional economy is, the graver the negative externalities of failures on the whole economic system. The "too big to fail" mechanism entails then 
a positive correlation between deficit and regional size. Hernandez Trillo et al (2002) confirm this idea in their work on Mexican regional governments. Conversely, in the four case study by Von Hagen et al (2000) this relationship is not found, rather the opposite one, especially in the German case (Seitz, 2000). They suggest that because the financial cost of bailing out a region increases with its size, the expected statistical correlation between subcentral deficit and regional size is negative ("too small to fail"). Moreover, according to García-Milá et al (2002), since payment for bailout is spread over all regions -by means of federal taxation- the price of bailout for one region decreases with the regions's income share. Then, incentives to borrowing will be stronger in smaller regions.

Politics may be also relevant for bailout expectations. Seitz (2000) suggests the existence of a political connection between the size of a region and its bailout expectations. The basic idea is that (not) bailing out a region has a (negative) positive effect on the political support of constituency to the incumbent in central government. However, the sign of this relationship is neither clear, mainly in countries with proportional representation systems. Bigger regions in political terms have more seats ("too big to fail"), but smaller regions are used to enjoying a lower ratio votes/seats. The malapportionment of most electoral systems makes the value of votes from different districts were distinct (Samuels and Snyder, 2001). Therefore, the political profitability of grants to smaller regions would be higher in relative terms ("too small to fail"). Last but not least, political affinity between central and subcentral governments increases the probability of bailout (Von Hagen et al (2000) and Nicolini et al (2002)). This relationship has been confirmed by Bevilaqua (2002) for Brazil and by Hall et al (2003) for Costa Rica.

Financial markets should also reflect the existence of bailout expectations. According to Lane (1993) and Bayoumi et al (1995), an efficient credit market discriminates among lenders depending on their individual solvency. On the contrary, bailout expectations generate no credit market discrimination because of the expected solidarity among creditors. So, financial discrimination (in terms of debt ratings and spreads) would be evidence against the bailout hypothesis. If creditors do not discriminate, an increase in the deficit of one regional government generates a negative 
externality on the rest. If creditors discriminate and use average debt as a yardstick, the same rise might generate a positive spillover (Landon and Smith, 2000).

Finally, a central government may wait for a financial crisis to intervene or increase grants to the most indebted regions before they go into a bankruptcy. This strategy would imply a positive cross-correlation between the stock of debt and discretionary grants (Burki et al, 1999). Empirical relationships motivated by bailout expectations are synthesized in table 2 .

TABLE 2: EMPIRICAL IMPLICATIONS OF BAILOUT MODELS

\begin{tabular}{||l||}
\hline SIMILAR EXPLOITATION OF LIMITS ON BORROWING \\
\hline $\begin{array}{l}\text { TOO BIG TO FAIL (I): NEGATIVE EXTERNALITIES ON THE NATIONAL ECONOMIC } \\
\text { SYSTEM } \\
\text { (Wildasin, 1997; Hernandez and Trillo, 2002) }\end{array}$ \\
\hline $\begin{array}{l}\text { TOO BIG TO FAIL (II): VOTES COUNT } \\
\text { (Seitz, 2000) }\end{array}$ \\
\hline $\begin{array}{l}\text { TOO SMALL TO FAIL (I): A CHEAP RESCUE FOR THE CENTRAL GOVERNMENT } \\
\text { (Seitz, 2000) }\end{array}$ \\
\hline $\begin{array}{l}\text { TOO SMALL TO FAIL (II): A LOW PRICE FOR SMALL REGIONS } \\
\text { (Garcia-Mila et al, 2002) }\end{array}$ \\
\hline $\begin{array}{l}\text { TOO SMALL TO FAIL (III): NO PROPORTIONALITY OF ELECTORAL SYSTEMS } \\
\text { (Samuels and Snyder, 2001; Monroe and Rose, 2000) }\end{array}$ \\
\hline $\begin{array}{l}\text { POLITICAL AFFINITY INCREASES EXPECTATIONS OF BAILOUT AND THEN PRESENT } \\
\text { DEFICIT } \\
\text { (Von Hagen et al, 2000; Nicolini et al, 2002; Belivaqua, 2000; Hall et al, 2003) }\end{array}$ \\
\hline $\begin{array}{l}\text { NO CREDIT MARKET DISCRIMINATION } \\
\text { (Lane, 1993; Bayoumi et al, 1995) }\end{array}$ \\
\hline $\begin{array}{l}\text { NEGATIVE EXTERNALITIES IN CREDIT MARKETS (SOLIDARITY AMONG LENDERS) } \\
\text { (Landon and Smith, 2000) }\end{array}$ \\
\hline $\begin{array}{l}\text { DEBT STOCKS EXPLAIN GRANT RISES } \\
\text { (Burki et al, 1999) }\end{array}$ \\
\hline
\end{tabular}

\section{FISCAL FEDERALISM IN SPAIN: AN OVERVIEW}

The Spanish Constitution sanctioned in 1978 gave way to a new organisation of the Spanish State with the creation of the Comunidades Autónomas (Autonomous Communities or ACs). Seventeen ACs were created. Each one is composed by one or several provinces -the range goes from 1 to 9-. The local governments at the provincial level are called Diputaciones. The relevance of their powers is much lower than that corresponding to regional and municipal governments. There are two and clear-cut sorts of ACs: the so-called forales ACs -Navarra and País Vasco- and the rest (common ACs). Due to historical reasons, the former enjoy a higher degree of autonomy and a radically 
different system of financing, which is translated into a higher level of resources per capita. Subcentral governments of Navarra and Pais Vasco collect all the taxes in their territories -business income tax, special excises, VAT and PIT among others- and transfer an amount to the State yearly. Both ACs can modify the structure of their fiscal system -except in the indirect taxes- subject to the harmonization rules imposed by the European Union and the central government.

The decentralization of spending powers towards the new regional tier has evolved in such a way that is now similar to that of federal countries such as Germany, USA, and Canada (Monasterio and Suárez-Pandiello, 2002; Aja, 2003). The ACs' participation in total Spanish public spending has risen to around $35 \%$ of the total after the devolution of powers on health-care to ten ACs in $2002^{3}$.

Decentralization patterns in the revenue side have been completely different. The vertical fiscal imbalance has been huge until 2002 and tax autonomy has been low. After several reforms of the financing system to reduce the gap, around 70 per cent of the public spending of common ACs in 1998 was still financed by means of grants. In any case, while it is true that there are significant constitutional limits to the creation of new taxes by the $\mathrm{ACs}^{4}$, they have enjoyed from the beginning the capacity to surcharge Personal Income Tax (PIT). And ACs have taken limited advantage of this possibility.

Although rule-based grants were predominant, periodical renegotiations of the financing system and discretional grants softened the subcentral budget constraints, opening the possibility of rent-seeking. Unconditional grants have been, by and large, the main source of revenues for regional governments in Spain, setting aside the special arrangements for Navarra and Pais Vasco. Equalization of fiscal capacity has been very strong. Moreover, the poorest regions have received more supplementary conditional

\footnotetext{
${ }^{3}$ Until 2002 (1999), Andalucía, Canarias, Catalunya, Galicia and Comunidad Valenciana were the only ACs with responsibilities in health (education). Because both public policies absorb more than fifty percent of total spending, the mean size of the budget for this group of ACs was much higher than in the rest.

${ }^{4}$ In particular, they cannot tax bases previously levied by the central government, nor tax rents or goods placed out of the own territory, nor hamper the movements of factors and goods across regions. Canarias is one exception in so far taxes on consumption are under the control of the regional government. Moreover, uniprovincial ACs also enjoy a slightly higher tax autonomy than multi-provincial ACs because they have assumed tax powers from the corresponding province.
} 
grants from the central government and the European Union to boost their economic performance.

Otherwise, limits on borrowing were higher and softer until $1992^{5}$. Before then the two most important limits were the golden rule (debt must be used to finance capital spending) and the sum of interest payments and debt refunds could not exceed $25 \%$ of current revenues. This second limit has not been very troublesome for the ACs because the initial debt stock was zero and the rise in current revenues has been very rapid, parallel to the decentralization of spending powers.

On the contrary, common ACs did not meet some of the conditions exposed in table 1. They enjoyed a high spending autonomy and spending responsibilities were clear. Statewide parties were strong and disciplined (Gunther et al, 2002). Although regional parties were also strong in Spain, their influence on national politics had only been felt since 1993 (until 2000). Both central government and the central bank reiterated their no responsibility on subcentral debt, especially in the early nineties when deficit seemed to be unsustainable (Ezquiaga and García, 2001). Finally, the social and political consolidation of subcentral governments has promoted the perception of their independence with respect to central government (Máiz et al, 2002).

\section{EXPLAINING THE DEFICIT OF SPANISH REGIONAL GOVERMENTS}

Empirical analysis is organized in three parts. Firstly, factors affecting the dynamics of total regional public deficits are discussed. Secondly, interregional disparities in deficits are analyzed, testing relationships contained in table 2 . Finally, the exploitation of limits on borrowing, financial markets discriminations and the determinants of grants to regions are examined. Because of their particularities, foral ACs are not considered in some of this empirical work. Data source and definitions for all variables used in this section are reported in table 3.

\footnotetext{
${ }^{5}$ Since borrowing is the only instrument to finance deficit, limiting indebtedness led to constraining the size of the deficit.
} 
TABLE 3: DEFINITION OF VARIABLES AND DATA SOURCES

\begin{tabular}{|c|c|c|}
\hline Name & Definition & Data Source \\
\hline & Public consumption deflator. Base year $=1986$ & $\begin{array}{l}\text { Instituto Nacional de Estadística } \\
\text { (INE, www.ine.es). }\end{array}$ \\
\hline AUTO & $\begin{array}{l}\text { Own revenues. Defined as the unweighted mean of regional data } \\
\text { expressed in pesetas, on per capita basis, and in real terms, by } \\
\text { deflating the current values using the national public consumption } \\
\text { deflator }\end{array}$ & $\begin{array}{l}\text { Ministerio de Economia y Hacienda } \\
\text { (MEH, several years, www.meh.es). }\end{array}$ \\
\hline$C A N$ & Dummy variable. It values 1 for Canarias and 0 for the rest of Acs & \\
\hline $\mathrm{D}$ & Regional deficit. Defined as $A U T O$ & $\begin{array}{l}\text { Ministerio de Economia y Hacienda } \\
\text { (MEH, several years, www.meh.es). }\end{array}$ \\
\hline$D C$ & Regional public debt & Banco de España (www.bde.es) \\
\hline DCPLUS & Regional public debt (including unconsolidated debt) & Banco de España (www.bde.es) \\
\hline $\boldsymbol{E}$ & Total public spending. & \\
\hline$G$ & Granted revenues. Defines as $A U T O$ & \\
\hline$G D P$ & Per capita GDP (Spanish mean=100) & FBBVA (http://bancoreg.fbbv.es) \\
\hline$I C$ & $\begin{array}{l}\text { Financial resources received by regions by means of the main } \\
\text { discretional grants program during 1992-1996: "Convenios de } \\
\text { Inversion" }\end{array}$ & $\begin{array}{l}\text { Instituto de Estudios Fiscales } \\
\text { (www.ief.es). }\end{array}$ \\
\hline INC87 & $\begin{array}{l}\text { Growth in granted revenues due to the reform of the financing } \\
\text { system of ACs in } 1987\end{array}$ & Utrilla $(2002$, row 4 in tables 1 and 4$)$ \\
\hline INC92 & $\begin{array}{l}\text { Growth in granted revenues due to the reform of the financing } \\
\text { system of ACs in } 1992\end{array}$ & Utrilla (2002, row 4 in tables 1 and 4$)$ \\
\hline INT & Interest payments. Defined as $A U T O$ & $\begin{array}{l}\text { Ministerio de Economia y Hacienda } \\
\text { (MEH, several years, www.meh.es). }\end{array}$ \\
\hline POLAF & $\begin{array}{c}\text { Dummy variable. It values } 1 \text { for regions ruled by the PSOE most } \\
\text { of the time from } 1982 \text { to } 1996 \text { (Andalucía, Asturias, Castilla-La } \\
\text { Mancha, Comunidad Valenciana, Extremadura, Madrid, Murcia } \\
\text { and La Rioja) and } 0 \text { for the rest }\end{array}$ & \\
\hline POP & Regional population & $\begin{array}{l}\text { Instituto Nacional de Estadística } \\
\text { (INE, www.ine.es). }\end{array}$ \\
\hline POW & $\begin{array}{c}\text { Dummy variable. It values } 1 \text { for regions with powers on public } \\
\text { health and education (Andalucía, Canarias, Comunidad } \\
\text { Valenciana, Catalunya and Galicia) and } 0 \text { for the rest }\end{array}$ & \\
\hline$R A T G D P$ & $\frac{G D P_{i} \cdot P O P_{i}}{\sum_{i=1}^{17}\left(G D P_{i} \cdot P O P_{i}\right)}$ & FBBVA (http://bancoreg.fbbv.es) \\
\hline RATPOP & $\frac{P O P_{i}}{\sum_{i=1}^{17} P O P_{i}}$ & $\begin{array}{l}\text { Instituto Nacional de Estadística } \\
\text { (INE, www.ine.es). }\end{array}$ \\
\hline STOCK86 & Per capita regional debt stocks in December 1986 & Banco de España (www.bde.es) \\
\hline STOCK91 & Per capita regional debt stocks in December 1991 & Banco de España (www.bde.es) \\
\hline$T$ & $\begin{array}{l}\text { Own taxes, calculated as total taxes minus ceded taxes. Defined as } \\
\qquad A U T O\end{array}$ & $\begin{array}{l}\text { Instituto de Estudios Fiscales } \\
\text { (www.ief.es). }\end{array}$ \\
\hline TREND & Time trend. It values 1 in 1990 and 13 in 2002 & \\
\hline UNI & $\begin{array}{l}\text { Dummy variable. It values } 1 \text { for uniprovincial ACs (Asturias, } \\
\text { Cantabria, Madrid, Murcia and La Rioja) and } 0 \text { for the rest. }\end{array}$ & \\
\hline
\end{tabular}


Figure 1 shows the evolution of regional deficit. The dotted line reflects the evolution of the weight of $D$ on the financing of total expenditures $(G)$. Foral ACs are not included. Although data was obtainable for 1984-1999 only, fiscal consolidation has followed afterwards. Moreover, recent legal changes will mean that subcentral deficit and borrowing will be an exceptional procedure from 2002 (González-Páramo, 2001).

FIGURE 1: THE EVOLUTION OF REGIONAL PUBLIC DEFICIT 1984-1999

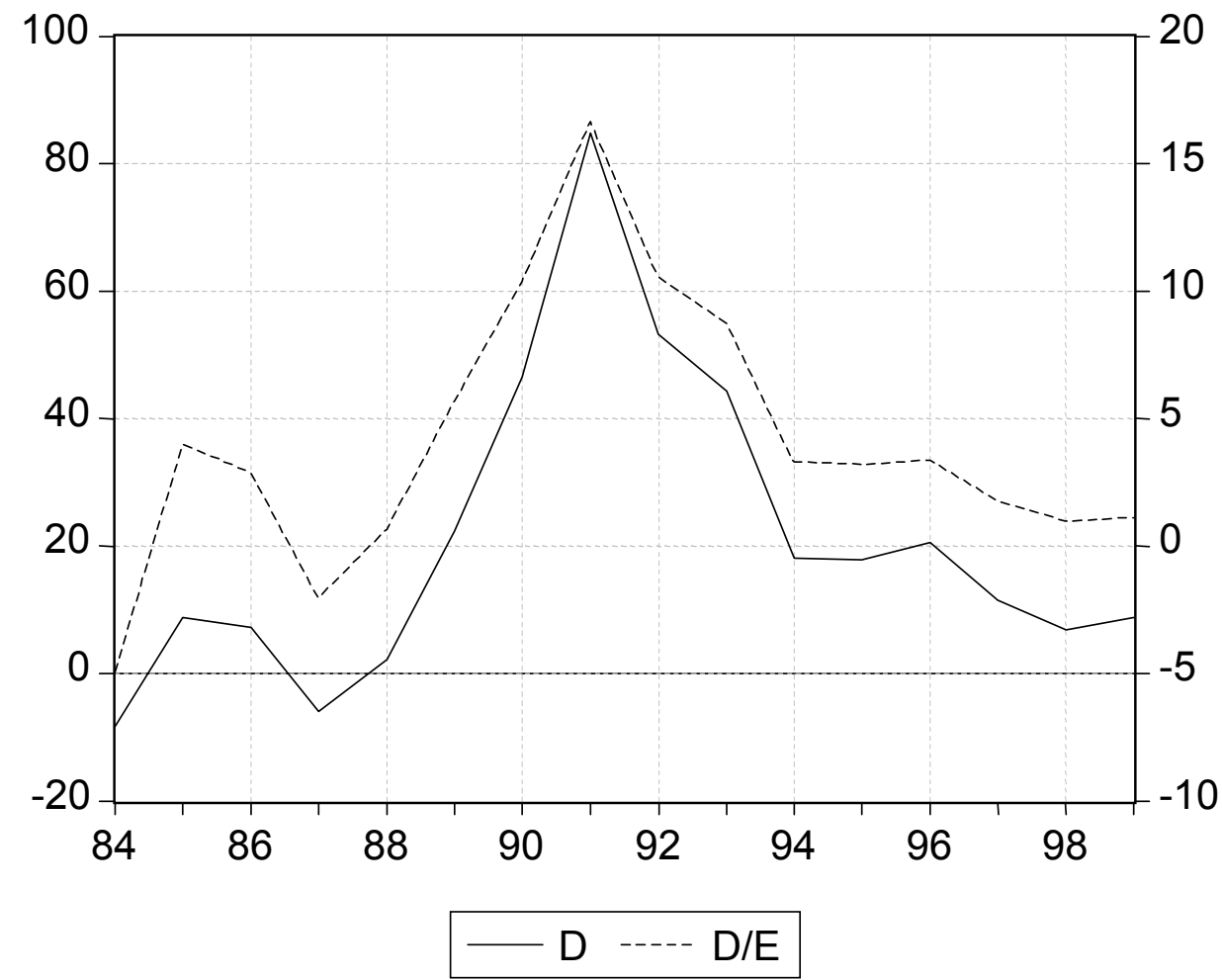

From 1984 to 1991 deficit increases with the devolution of spending responsibilities, except in 1987 due to a reform of the financing system that raised unconditional grants to ACs. Since 1991 deficit dropped because of a new reform of the financing system in 1992 (increasing overall resources again) and the introduction of additional limits on borrowing that have been progressively stronger (Vallés, 2002).

Figure 2 shows the evolution of spending, granted revenues $(G)$, own revenues $(A U T O)$ and deficit. Variable AUTO includes deficit, own taxes and other minor 
revenues $^{6}$. Until 1991 the deficit was the result of a growth of spending higher than the corresponding to granted revenues and the stagnation of own taxes and other revenues. Since 1992, the weight of $D$ in $A U T O$ decreases and the weight of own taxes and other revenues increases. The consolidation of the new tier would make the expansion of own taxes easier.

FIGURE 2: THE EVOLUTION OF SPENDING, GRANTED REVENUES, AUTONOMOUS REVENUES AND DEFICIT 1984-1999

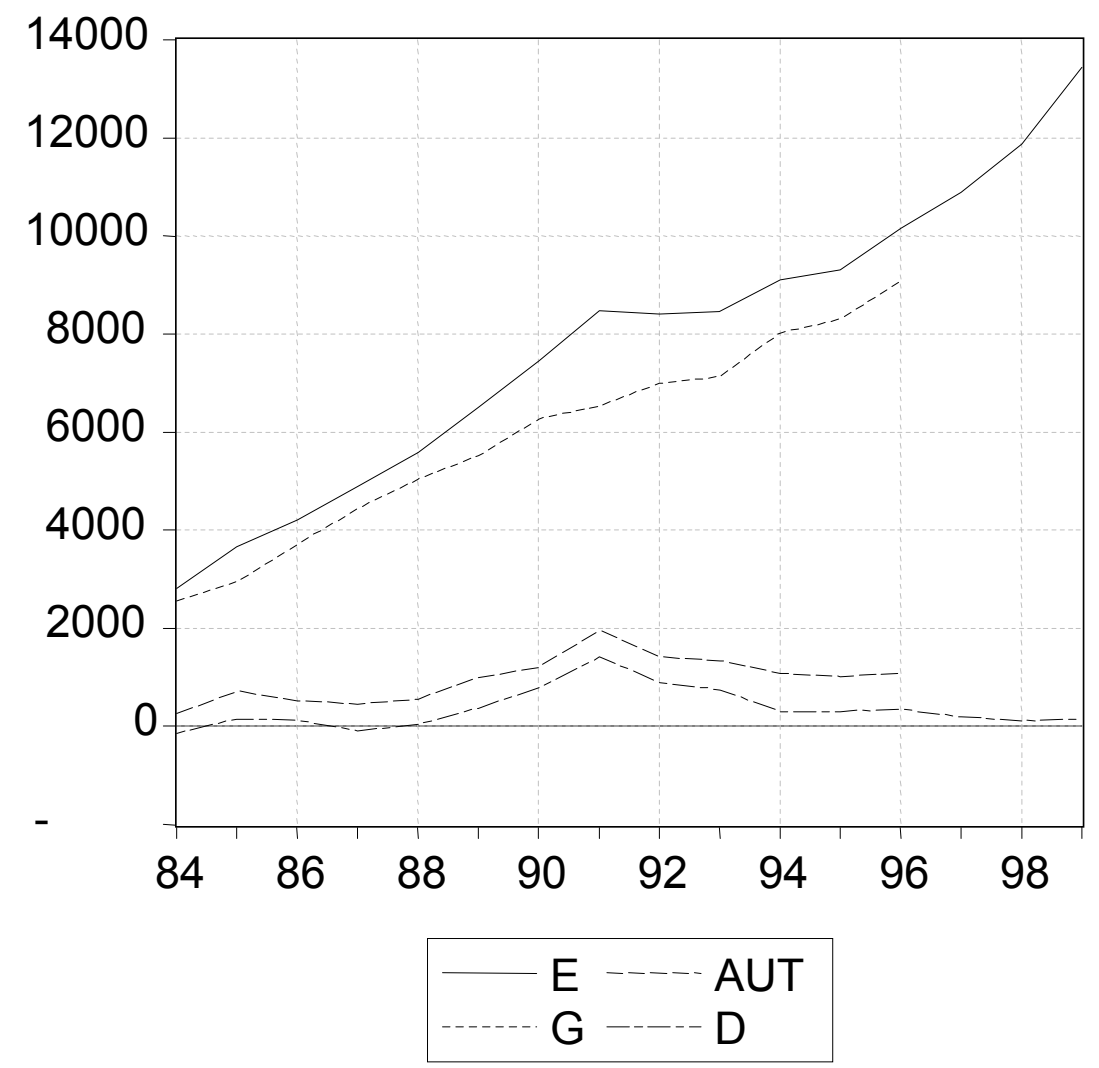

The main reason for deficit cut since 1992 is due to the existence of additional limits on borrowing that have become progressively stronger. However, the reduction in deficit was accompanied by a significant increase in the debt of the unconsolidated

\footnotetext{
${ }^{6}$ In 1997 there was a structural change in the financing system changing the relative weight of granted revenues and own taxes. Before 1997, the collection (tax administration and revenues) of a set of taxes (the net wealth tax, taxes on donations and inheritances, the patrimonial transmissions tax and an array of gambling taxes) was ceded to ACs without normative powers. Then ceded taxes were closer to a revenue sharing formula with a regional participation of $100 \%$ and considered granted revenues. Differences among regions in tax collections were compensated with unconditional grants to equalize fiscal capacities. The reform of the financing system in 1997 altered the nature of these taxes. Since then ACs have constrained powers to change tax rates or deductions, so they must be considered own taxes and then incorporated into AUTO. Resulting differences among regions in total own tax revenues (highly correlated with per capita GDP) should be understood as the effect of a structural change and not the consequence of a dramatic change in fiscal preferences.
} 
public sector. By definition, its borrowing is not subject to the mentioned debt limits, offering a way to hide deficit. Figure 3 reflects the evolution of the debt of all the ACs. $D C$ excludes unconsolidated debt. DCPLUS includes it. Unfortunately, individual data on unconsolidated debt is not available.

FIGURE 3: THE EVOLUTION OF TOTAL REGIONAL PUBLIC DEBT STOCK 1990-2002 (BILLIONS OF EUROS. CURRENT PRICES)

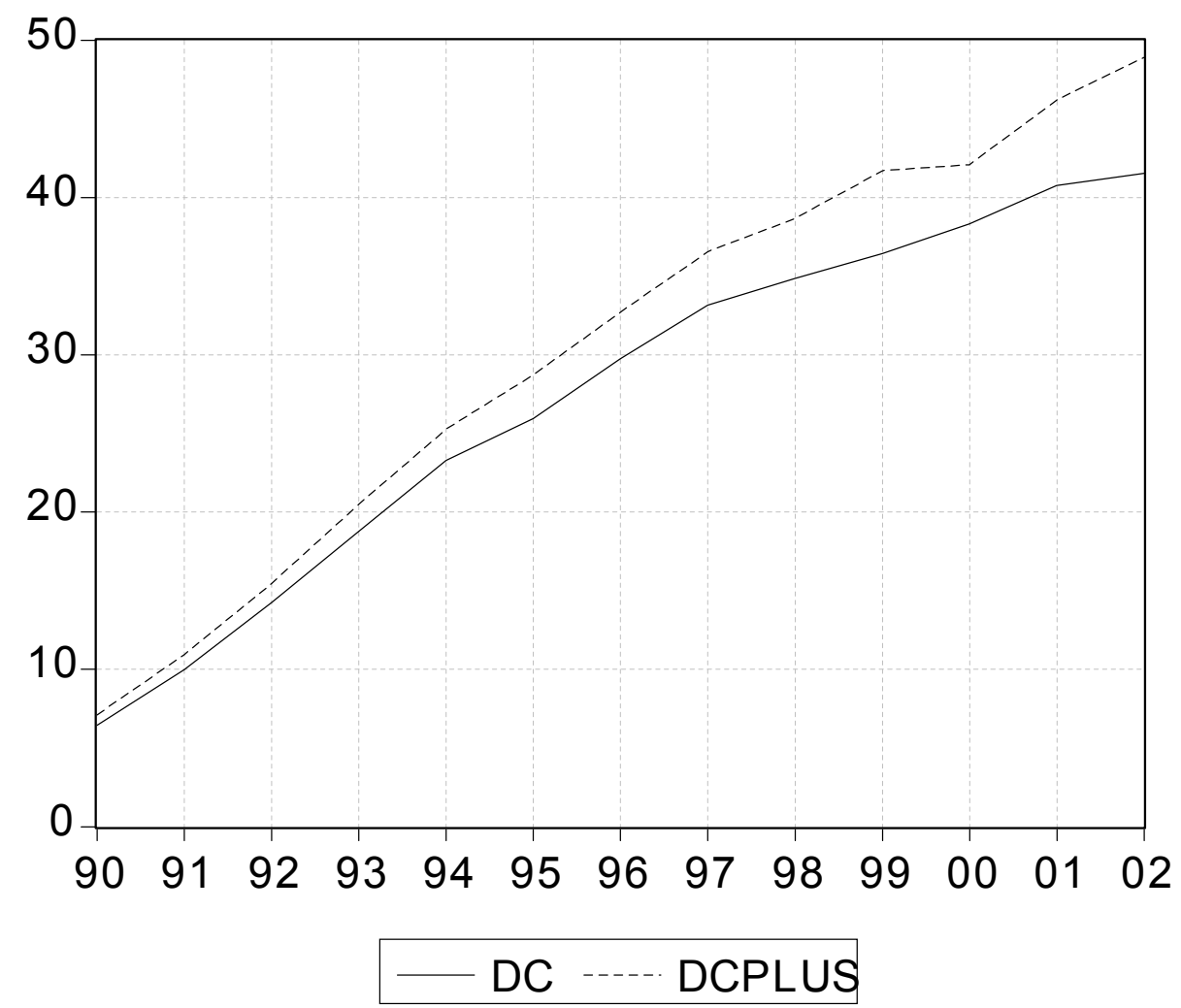

While both series are clearly reducing their growth, the gap between them increases with time. To cast some light on the consequences of this strategy, the following equation has been estimated for both $D C$ and $D C P L U S$ as explained variables and a time trend as explicative variable:

$D C_{t}=\beta_{1}+\beta_{2} \cdot \operatorname{TREND}_{t}+\beta_{3} \cdot \operatorname{TREND}_{t}^{2}+\varepsilon_{i}$

In table 4 results are synthesized. Estimates have been used as the basis of two simulations. According to them $D C$ would attain its maximum in 2005. The stock of debt would be then 43.4 billions of euros (41.5 in 2002). On the contrary, DCPLUS would not stop to growth until 2008 attaining 53.9 billions of euros (48.9 in 2002). 
TABLE 4: THE EVOLUTION OF THE REGIONAL DEBT STOCK (1990-2002). OLS ESTIMATES

\begin{tabular}{|c|c|c|}
\hline EXPLAINED VARIABLE & $D C$ & DCPLUS \\
\hline INTERCEPT & $\begin{array}{l}0.62 \\
(1.1)\end{array}$ & $\begin{array}{l}1.15 \\
(1.4) \\
\end{array}$ \\
\hline TREND & $\begin{array}{c}5.25 \\
(29.0) \\
\end{array}$ & $\begin{array}{c}5.43 \\
(20.7) \\
\end{array}$ \\
\hline TREND $^{2}$ & $\begin{array}{c}-0.16 \\
(-12.8) \\
\end{array}$ & $\begin{array}{l}-0.14 \\
(-7.7) \\
\end{array}$ \\
\hline $\mathrm{R}^{2}$ & 0.998 & 0.997 \\
\hline D-W & 1.78 & 1.86 \\
\hline RESET (p-value) & 0.30 & 0.89 \\
\hline Number of observations & 13 & 13 \\
\hline Simulated maximum (Year) & 2005 & 2008 \\
\hline Simulated maximum (Billions of euros) & 43.4 & 53.9 \\
\hline
\end{tabular}

Notes: Standard t-statistics in parenthesis. $D-W$ is the Durbin-Watson test on serial autocorrelation. RESET is the Ramsey's test on the null hypothesis of no specification errors.

Last comment is about the relationship between borrowing and the interest rate. During the late eighties and the beginning of the nineties, credit markets were euphoric over financial risk-taking in Spain (Ezquiaga and García, 2001). It helped ACs in their strategy of indebtedness. In the second half of the nineties interest rates dropped dramatically in Spain. However, the reason for the cut in spreads was precisely of a fiscal consolidation. Therefore, its effect on the cost of the stock of debt is more evident than its effect on current deficit. Figure 4 reflects the evolution of interest payments (INT) and deficit.

FIGURE 4: THE COST OF THE DEBT 1984-1999 (EUROS PER CAPITA. CONSTANT PRICES).

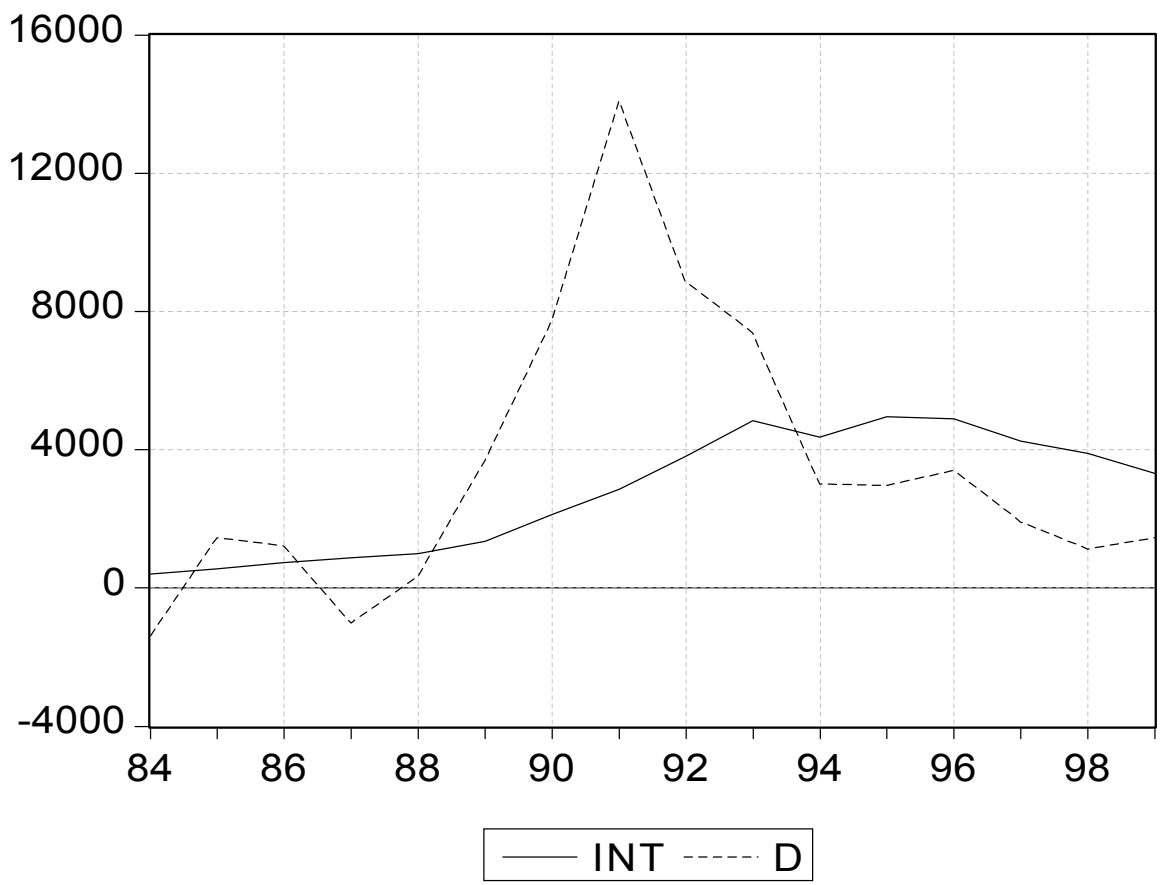




\section{INTERREGIONAL DIFFERENCES}

To test relationships shown in table 2, disposing of a simple benchmark model is convenient. Its point of departure will be Grossman (1989). He supposes a downsian government that tries to maximize a popularity function when choosing the level and composition of its revenues ${ }^{7}$ :

$$
\begin{aligned}
& \max _{T} V=V(E, T) \\
& \text { s.t: } \\
& E=G+T \\
& \text { with: } \\
& V^{\prime}(E)>0 ; \quad V^{\prime}(T)<0 ; \quad V^{\prime \prime}(E)<0 ; \quad V^{\prime \prime}(T)>0
\end{aligned}
$$

Where $V$ is the popularity function, $E$ is public spending, $G$ is grants and $T$ taxes. Firstorder maximization condition is:

$$
V^{\prime}(T)=-V^{\prime}(E)
$$

Assuming that grants are exogenous, the government chooses $T$ to equate the marginal effects of spending and taxes. Once optimal taxes are fixed, total revenue and then spending are determined. The incorporation of deficit is direct by inserting the model into a two-period inter-temporal framework:

$$
\begin{aligned}
& \max _{T_{1}, T_{2}, D} V=V\left(E_{1}, E_{2}, T_{1}, T_{2}\right) \\
& \text { s.t.: } \\
& E_{1}=G_{1}+T_{1}+D \\
& E_{2}=G_{2}+T_{2}-D(1+r) \\
& \text { with: } \\
& V^{\prime}\left(E_{i}\right)>0 ; \quad V^{\prime}\left(T_{i}\right)<0 ; \quad V^{\prime \prime}\left(E_{i}\right)<0 ; \quad V^{\prime \prime}\left(T_{i}\right)>0
\end{aligned}
$$

Now $D$ is the deficit and $r$ the interest rate. First-order maximization condition is:

$$
V^{\prime}\left(T_{1}\right)=-V^{\prime}\left(E_{1}\right)=(1+r) V^{\prime}\left(T_{2}\right)=-(1+r) V^{\prime}\left(E_{2}\right)
$$

Looking at figure 1 it seems that regions have been permanently placed in a period of deficit that could be interpreted as period 1 in the model. However, variations in the level of deficit would be indicating changes in the optimization problem through time.

\footnotetext{
${ }^{7}$ Originally, Grossman applied the model to the central government, so grants were among expenditures and not revenues. This model is analogous to the first of those developed by García-Milá et al (2002). However, they assume that: i) regional governments act to maximize the utility of a representative consumer, and ii) central government does not devolve taxing authority until period two. Anyway, main results are quite similar: per capita borrowing has a negative relation with per capita grants and a positive
} 
For instance, changes in limits on borrowing, or changes in the marginal effect of taxes already mentioned.

Inter-regional differences in own resources in period 1 could be explained by disparities in:

- The marginal effect of spending on popularity

- The volume of grants

- The marginal effects of taxes on popularity

For the Spanish case, per capita GDP may control by inter-regional differences in marginal effects of spending and taxes (assuming that the higher the per capita GDP, the higher the marginal effect of public spending and the lower the marginal effect of taxes on electoral support) and disparities in grants (because of capital grants attached to European and Spanish regional policies and devoted mainly to the poorest regions). On the other hand, marginal effects of spending may also depend on differences in the level of spending responsibilities (assuming that the optimal level of total spending grows with the level of powers) or in the cost of public services (spending needs).

The following equation has been estimated to explain regional disparities in terms of deficit:

$D_{i}=\beta_{1}+\beta_{2} \cdot C A N_{i}+\beta_{3} \cdot P O W_{i}+\beta_{4} \cdot G D P_{i}+\varepsilon_{i}$

$C A N$ is included to control by differences in the financing system of Canarias, which are translated into a higher level of tax autonomy and tax collection. Variable $P O W$ controls by differences in the level of powers ${ }^{8}$. Foral ACs are excluded again. Econometric estimates of the equation are reported in the first row of table 5. Cross-section specific means for the whole period 1984-1996 have been used ${ }^{9}$. The reason for excluding data from 1997 to 1999 is that results will be compared with the corresponding to own taxes.

one with per capita income. García-Milá et al (2002) analyze several theoretical possibilities in financial relations between two fiscal tiers. Bailout is just one of them.

${ }^{8}$ Spending needs indexes estimated by Castells and Solé (2000) were also included in regressions as control variables. However they were not statistically significant.

${ }^{9}$ Because the values of regressors do not change through time significantly, panel data information would be redundant. Moreover, while sample size increases, variances of regressors and residuals do not 
According to White's test of heteroscedasticity and the RESET test, the econometric specification is correct and Ordinary Least Squares (OLS) the best method of estimate. The goodness of fit is high. The sample size is not large, but it includes total population and results are straightforward. Regressors are highly significant.

RESULT 1: According to estimates, deficit was higher in richer regions and in ACs with more powers

Regional sizes, both political and economic, are measured by two different variables: relative population $(R A T P O P)$ and relative GDP $(R A T G D P)$, respectively. Both ratios do not change significantly during 1984-1996. Simple correlations between values at the beginning and the end of the period are 0.998 (RATPOP) and 0.999 $(R A T G D P)$. Setting aside the expected high correlation between RATPOP and RATGDP, multicollinearity does not seem to be a problem (table 6). Multiple correlations are also moderate. The two coefficients of determination for the regressions of $R A T G D P$ and $R A T P O P$ on the other regressors in rows 2 and 3 of table 5 are 0.536 and 0.562 . It is clearly less than the overall $\mathrm{R}^{2}$ in both cases $(0.883$ and 0.881$)$.

RESULT 2: Regional sizes, both political and economic, are not relevant to explain differences in regional deficits

significantly change. Therefore, corresponding t-statistics become "inflated". In particular, for a bivariate OLS estimate:

$\hat{\sigma}(b)=\sqrt{\frac{\frac{n}{n-2} \hat{\sigma}^{2}(e)}{n \hat{\sigma}^{2}(x)}}=\sqrt{\frac{1}{n-2} \frac{\hat{\sigma}^{2}(e)}{\hat{\sigma}^{2}(x)}}$

where $n$ is the number of observations, $x$ the explicative variable and $e$ residuals.

Simple correlation between regional per capita GDP at the beginning and the end of the sample is 0.95 . 
TABLE 5: THE DETERMINANTS OF DEFICITS AND OWN TAXES. CROSS-SECTION DATA (1984-1999). OLS ESTIMATES

\begin{tabular}{|c|c|c|c|c|c|c|c|c|}
\hline $\begin{array}{l}\text { DEPENDENT } \\
\text { VARIABLE } \\
\end{array}$ & $\begin{array}{c}D \\
(1984-96) \\
\end{array}$ & $\begin{array}{c}D \\
(1984-96) \\
\end{array}$ & $\begin{array}{c}D \\
(1984-96) \\
\end{array}$ & $\begin{array}{c}D \\
(1984-96) \\
\end{array}$ & $\begin{array}{c}D \\
(1995-96) \\
\end{array}$ & $\begin{array}{c}D \\
(1997-99) \\
\end{array}$ & $\begin{array}{c}T \\
(1984-96) \\
\end{array}$ & $\begin{array}{c}T \\
(1995-96) \\
\end{array}$ \\
\hline Intercept & $\begin{array}{c}-826 \\
(-0.62) \\
\end{array}$ & $\begin{array}{l}-276 \\
(-0.20)\end{array}$ & $\begin{array}{c}-917 \\
(-0.71) \\
\end{array}$ & $\begin{array}{l}-1097 \\
(-0.66) \\
\end{array}$ & $\begin{array}{l}-1027 \\
(-0.23) \\
\end{array}$ & $\begin{array}{c}-5 \\
(-0.00) \\
\end{array}$ & $\begin{array}{l}-2384 \\
(-1.03) \\
\end{array}$ & $\begin{array}{l}-6237 \\
(-2.02) \\
\end{array}$ \\
\hline$C A N$ & $\begin{array}{l}-3648 \\
(-3.11)\end{array}$ & $\begin{array}{l}-2687 \\
(-2.25)\end{array}$ & $\begin{array}{l}-2807 \\
(-2.11)\end{array}$ & $\begin{array}{l}-3556 \\
(-2.82)\end{array}$ & $\begin{array}{l}2007 \\
(0.51)\end{array}$ & $\begin{array}{l}-1812 \\
(-1.42)\end{array}$ & $\begin{array}{c}21886 \\
(10.90)\end{array}$ & $\begin{array}{l}24291 \\
(9.05)\end{array}$ \\
\hline$P O W$ & $\begin{array}{c}5032 \\
(8.08) \\
\end{array}$ & $\begin{array}{c}4258 \\
(5.12) \\
\end{array}$ & $\begin{array}{l}4188 \\
(4.59) \\
\end{array}$ & $\begin{array}{r}5059 \\
(7.71) \\
\end{array}$ & $\begin{array}{r}6926 \\
(3.27) \\
\end{array}$ & $\begin{array}{c}1121 \\
(1.64) \\
\end{array}$ & $\begin{array}{l}1037 \\
(0.86) \\
\end{array}$ & $\begin{array}{c}2005 \\
(1.24) \\
\end{array}$ \\
\hline$G D P$ & $\begin{array}{c}35 \\
(2.66) \\
\end{array}$ & $\begin{array}{c}25 \\
(1.77) \\
\end{array}$ & $\begin{array}{c}32 \\
(2.46) \\
\end{array}$ & $\begin{array}{c}36 \\
(2.48) \\
\end{array}$ & $\begin{array}{c}18 \\
(0.42) \\
\end{array}$ & $\begin{array}{c}3 \\
(0.18) \\
\end{array}$ & $\begin{array}{c}39 \\
(1.76) \\
\end{array}$ & $\begin{array}{c}90 \\
(3.13) \\
\end{array}$ \\
\hline RATGDP & & $\begin{array}{c}92 \\
(1.34) \\
\end{array}$ & & & & & & \\
\hline RATPOP & & & $\begin{array}{c}95 \\
(1.24) \\
\end{array}$ & & & & & \\
\hline$P O L A F$ & & & & $\begin{array}{c}191 \\
(0.30)\end{array}$ & & & & \\
\hline$\overline{U N I}$ & & & & & & & $\begin{array}{l}4117 \\
(3.61) \\
\end{array}$ & $\begin{array}{l}3220 \\
(2.13) \\
\end{array}$ \\
\hline $\begin{array}{c}\text { RESET } \\
(\mathrm{p} \text {-value) }\end{array}$ & 0.99 & 0.89 & 0.86 & 0.89 & 0.90 & 0.47 & 0.60 & 0.18 \\
\hline $\begin{array}{c}\text { White } \\
\text { (p-value) }\end{array}$ & 0.68 & 0.74 & 0.80 & 0.79 & 0.58 & 0.36 & 0.54 & 0.52 \\
\hline $\begin{array}{l}\text { F-statistic } \\
\text { (p-value) }\end{array}$ & & & & & 0.02 & 0.37 & & \\
\hline $\mathrm{R}^{2}$ & 0.862 & 0.883 & 0.881 & 0.863 & 0.566 & 0.237 & 0.936 & 0.919 \\
\hline $\begin{array}{l}\text { Number of } \\
\text { observations }\end{array}$ & 15 & 15 & 15 & 15 & 15 & 15 & 15 & 15 \\
\hline
\end{tabular}

Notes: Standard t-statistics in parenthesis. RESET is the Ramsey's test on the null hypothesis of no specification errors. White is the White's test on the null hypothesis of homocedasticity. F-statistic is a joint test of the hypothesis that all the coefficientes except the intercept are zero.

TABLE 6: CORRELATIONS AMONG EXPLICATIVE VARIABLES (CROSS-SECTION MEANS FOR 1984-1996)

\begin{tabular}{||c|c|c|c|c|c|c|c||}
\hline \hline & $P O W$ & $P O L A F$ & $G D P$ & RATPOP & RATGDP & CAN & UNI \\
\hline POW & 1 & & & & & & \\
\hline$P O L A F$ & -0.19 & 1 & & & & & \\
\hline GDP & -0.11 & -0.33 & 1 & & & & \\
\hline$R A T P O P$ & $\mathbf{0 . 6 3}^{*}$ & 0.10 & 0.05 & 1 & & & \\
\hline$R A T G D P$ & $\mathbf{0 . 5 3}^{*}$ & 0.02 & 0.32 & $\mathbf{0 . 9 4}$ & 1 & & \\
\hline$C A N$ & 0.38 & -0.29 & -0.01 & -0.12 & -0.11 & 1 & \\
\hline$U N I$ & -0.50 & 0.38 & 0.11 & -0.29 & -0.19 & -0.19 & 1 \\
\hline
\end{tabular}

*Significant at $5 \%$ level.

The dummy variable $P O L A F$ is included in the basic specification to test the role played by political affinities (row 4 of table 5). Although its sign is positive, its significance is very low. 
RESULT 3: Political affinity between incumbents in central and regional tiers (POLAF) is neither relevant to explain differences in deficit

To compare choices on deficit with those on own taxes $(T)$, another equation has been estimated. A dummy variable $(U N I)$ is also included to control by the slightly higher tax autonomy of uniprovincial ACs. Equation to estimate is then:

$T_{i}=\beta_{1}+\beta_{2} \cdot U N I_{i}+\beta_{3} \cdot C A N_{i}+\beta_{4} \cdot P O W_{i}+\beta_{5} \cdot G D P_{i}+\varepsilon_{i}$

The main results are shown in the seventh row of table 5. Both $U N I$ and CAN are significant, but not $P O W$ and $G D P$. Things change when only the last part of the sample is examined (row 8). Using cross-section specific means for the period 1995-1996, GDP (in 1995) becomes highly significant and POW increases its significance.

Deficit behavior is the opposite. With data for 1995-96, GDP is not statistically significant and $P O W$ reduces its significance substantially (row 5). The p-value corresponding to the joint test of the hypothesis that all the coefficients except the intercept are zero is 0.02 . With data for 1997-99 (data for GDP in 1997) any explicative variable is relevant (row 6). The p-value of the F-statistic is now 0.37.

RESULT 4: Regions with higher levels of per capita GDP and spending responsibilities choose higher deficits but do not collect more taxes if one looks at the whole period. Results are the opposite once attention is paid to the last part of the sample, when limits on borrowing are tighter and political power to tax increases with the consolidation of the new tier ${ }^{10}$. Then per capita GDP becomes highly significant and POW increases its significance when explaining regional own taxes; and both regressors are not relevant to explain regional deficits

\footnotetext{
${ }^{10}$ Lago-Peñas and Lago-Peñas (2001) show that regional economic performance does not affect regional electoral results during the eighties but are important to explain electoral outcomes in the nineties. At the same time, electoral dynamics in general elections are more relevant during the eighties helping to explain what happens at regional level. These results are interpreted as evidence of an institutional consolidation process that is translated into a progressive independence of both tiers.
} 
García-Milá et al (2002) also deal with the bailout problem in Spain. Some of the results presented above corroborate their conclusions. When explaining per capita regional borrowing during 1984-1995, per capita income and the level of spending powers are significant variables. On the contrary, they find that the share of aggregate income and aggregate population are significant for ACs with more spending responsibilities but not for the rest. In order to test it interactions between the level of spending responsibilities and the size of regions were included into their estimates.

One possible explanation for differences in results might be multicollinearity. Simple correlations between POW, on the one hand, and RATPOP and RATGDP, on the other, are 0.63 and 0.53 , respectively (table 6). Simple correlations between $P O W$, on the one hand, and $R A T P O P^{*} P O W$ and $R A T G D P^{*} P O W$, on the other, rise until 0.86 and 0.84 , respectively. Hence, including $P O W$ and $R A T P O P * P O W$ (or $R A T G D P^{*} P O P$ ) simultaneously may be troublesome.

THE EXPLOITATION OF LIMITS ON BORROWING, MARKET DISCRIMINATION AND THE DETERMINANTS OF GRANTS

The three most relevant limits on borrowing met by ACs have been the following:

i) The golden rule

ii) The sum of interest payments and debt refund can not be more than the $25 \%$ of current revenues

iii) Since 1992 ACs must meet deficit limits accorded with central government to guarantee the achievement of fiscal constraints laid down by the European Monetary Union.

Monasterio et al (1999) analyze the performance of ACs during the period 199097. In general, the regions with more difficulties to meet this set of conditions would have been Catalunya and Comunidad Valenciana (the two richest among the ACs with powers in health-care and education) and Madrid ${ }^{11}$. From the six poorest regions, only Murcia would have approached the limits.

\footnotetext{
${ }^{11}$ With 1991 data, mean per capita GDP were the following (Spain=100): Baleares (143), Madrid (130), Catalunya (126), Navarra (116), País Vasco (110), Aragón (109), La Rioja (107), Comunidad Valenciana
} 
RESULT 5: There are differences among the regions in the exploitation of limits on borrowing

With respect to credit market discriminations, available evidence shows that the most indebted ACs are effectively discriminated against in terms of credit ratings (Monasterio et al, 1999) and spreads (Alcalde and Vallés, 2002). Unfortunately, the existence and sign of externalities in credit markets are not analyzed.

RESULT 6: Credit markets discriminate against the most indebted Autonomous Communities

Finally, relationships between regional debt, on the one hand, and increases in unconditional grants and the volume of discretional grants, on the other, have been examined. The reforms of the financing system of ACs in 1987 and 1992 increased grants for ACs. This is the explained variable in rows 1 and 2 of table 7. Political affinity and per capita debt stock in December 1986 (STOCK86) do not explain differences in increases in 1987 (row 1). Variables POLAF and STOCK91 are more relevant when explaining rises in 1992, but they are only significant at $10 \%$ level (row 2). Finally, in row 3 the determinants of most important discretional grants program are checked. Correlation between per capita discretional grants during 1992-1996 (IC) and per capita debt stock in December 1991 is negative, but not significant at usual levels. On the contrary, correlation with POLAF is positive and significant at $10 \%$.

RESULT 7: While increases in both based-rule grants and discretionary grants might be fairly interpreted as evidence of the strength of regional governments and the softness of their budget constraints, it is not clear that the distribution of additional resources has impinged upon bailout expectations. Stocks of regional public debt are not relevant to explain rises in grants. 
TABLE 7: THE DETERMINANTS OF GRANTS. CROSS-SECTION DATA. OLS ESTIMATES.

\begin{tabular}{||c|c|c|c||}
\hline $\begin{array}{c}\text { DEPENDENT } \\
\text { VARIABLE }\end{array}$ & INC87 & INC92 & $\begin{array}{c}\text { IC } \\
1992-96\end{array}$ \\
\hline Intercept & $\begin{array}{c}7.57 \\
(3.12)\end{array}$ & $\begin{array}{c}0.64 \\
(0.35)\end{array}$ & $\begin{array}{c}11566 \\
(2.20)\end{array}$ \\
\hline STOCK86 & $\begin{array}{c}0.00002 \\
(0.09)\end{array}$ & $\begin{array}{c}0.00007 \\
(1.88)\end{array}$ & $\begin{array}{c}-0.03 \\
(-0.24)\end{array}$ \\
\hline STOCK91 & & $\begin{array}{c}2.61 \\
(1.71)\end{array}$ & $\begin{array}{c}8105 \\
(1.83)\end{array}$ \\
\hline POLAF & $\begin{array}{c}-0.15 \\
(-0.06)\end{array}$ & 0.34 & 0.50 \\
\hline $\begin{array}{c}\text { RESET } \\
\text { (p-value) }\end{array}$ & 0.03 & 0.59 & 0.16 \\
\hline $\begin{array}{c}\text { White } \\
\text { (p-value) }\end{array}$ & 0.75 & 0.09 & 0.21 \\
\hline $\begin{array}{c}\text { F-statistic } \\
\text { (p-value) }\end{array}$ & 0.98 & 0.326 & 0.227 \\
\hline R & 0.011 & 15 & 15 \\
\hline $\begin{array}{l}\text { Number of } \\
\text { observations }\end{array}$ & 15 & & \\
\hline
\end{tabular}

Notes: Standard t-statistics in parenthesis. RESET is the Ramsey's test on the null hypothesis of no specification errors. White is the White's test on the null hypothesis of homocedasticity. F-statistic is a joint test of the hypothesis that all the coefficientes except the intercept are zero.

\section{CONCLUSION}

According to empirical evidence shown in this paper, the bailout hypothesis would not be the best explanation for regional government deficits in Spain. Effectively, some conditions that encourage bailout expectations hold in the past: tax autonomy was low and limits on borrowing were high and soft until the middle of the nineties. Although rule-based grants were predominant, periodical renegotiations of the financing system and discretional grants softened subcentral budget constraints.

However, the behavior of central and subcentral governments and credit markets does not meet the empirical implications of the bailout hypothesis discussed in section two. On the contrary, it seems to back up the benchmark model detailed in section four. From this perspective, ACs would have chosen the level and composition of own resources according to their needs, legal limits on borrowing and the political costs of the several sources of revenues. 


\section{REFERENCES}

-Aja, E. (2003): “El Estado Autonómico: Federalismo y hechos diferenciales”, second edition, Madrid: Alianza.

-Alcalde, N. and Vallés, J. (2002): “El mercado financiero y el racionamiento del endeudamiento autonómico", Papeles de Trabajo, 4/02, Madrid: IEF.

-Bayoumi, T.; Goldstein, M. and Woglom, G. (1995): “Do Credit Markets Discipline Sovereign Borrowers? Evidence from U.S. States", Journal of Money, Credit and Banking, 27.

-Bevilaqua, A.S. (2002): "State Government Bailouts in Brazil", Inter-American Development Bank, Research Network Working Paper, R-447.

-Bird, R.M. and Tassonyi, A. (2003): “Constraining Subnational Fiscal Behavior in Canada: Different Approaches, Similar Results?” in Rodden, J.; Eskeland, G.S. and Litvack, J.I. (Eds.): Fiscal Decentralization and the Challenge of Hard Budget Constraints, Cambridge, Mass: MIT Press.

-Bordignon, M. and Turati, G. (2003): "Bailing out Expectations and Health Expenditure in Italy", CESifo Working Paper, 1036.

-Burki, S.J.; Perry. G.E. and Dillinger, W.R. (1999): Beyond the Center: Decentralizing the State, Washington: The World Bank.

-Castells, A. and Solé, A. (2000): Cuantificación de las necesidades de gasto de las Comunidades Autónomas. Metodología y aplicación práctica, Madrid: IEF.

-Cooper, R.; Kempf, H. and Peled, D. (2004): “Is It or Is It Ain't My Obligation: Regional Debt in Monetary Unions”, NBER Working Papers, 10239.

-Dahlberg, M. and Pettersson-Lidbom, P. (2003): “The Bailout problem: An Empirical Approach", Paper presented at the $59^{\text {th }}$ IIPF Meeting, Prague.

-Ezquiaga, I. and García, F. (2001): Finanzas autonómicas, Madrid: Consultores de las Administraciones Públicas.

-García-Milá, T.; Goodspeed, T.J.; and McGuire, T.J. (2002): Fiscal Decentralization Policies and Sub-National Government Debt in evolving federations, Revised Draft (28 May 2002), http://econ.hunter.cuny.edu/faculty/goodspeed/papers/fiscal.pdf.

-Goodspeed, T. (2002): "Bailouts in a federation", International Tax and Public Finance, 9, 409-421.

-González-Páramo, J.M. (2001): Costes y beneficios de la disciplina fiscal: la Ley de Estabilidad Presupuestaria en perspectiva, Madrid: IEF. 
-Grossman, P.J. (1989): "Intergovernmental Grants and Grantor Government OwnPurpose Expenditures", National Tax Journal, 42.

-Gunther, R.; Montero, J.R. and Linz, J.J. (Eds.) (2002): Political Parties: Old Concepts and New Challenges, Oxford: Oxford University Press.

-Hall, L.J.; Arce, G.E. and Monge-Naranjo, A. (2002): "Bailouts in Costa Rica as a Result of Government Centralization and Discretionary Transfers", Inter-American Development Bank, Research Network Working Paper, R-475.

-Hernandez Trillo, F.; Diaz, A. and Gamboa, R. (2002): "Fiscal Decentralization in Mexico: The Bailout Problem", Inter-American Development Bank, Research Network Working Paper, R-447.

-Inman, R.P. (2003): “Transfers and Bailouts: Enforcing Local Fiscal Discipline with Lessons from U.S. federalism” in Rodden, J.; Eskeland, G.S. and Litvack, J.I. (Eds.): Fiscal Decentralization and the Challenge of Hard Budget Constraints, Cambridge, Mass: MIT Press.

-Kornai, J. (1986): “The Soft Budget Constraint”, Kyklos, 39 (1).

-Lago-Peñas, I and Lago-Peñas, S. (2001): "La influencia de los resultados económicos sobre el apoyo electoral de los gobiernos autonómicos, 1980-1997”, Revista Española de Investigaciones Sociológicas, 93.

-Landon, S. and Smith, C.E. (2000): "Government Debt Spillovers and Creditworthiness in a federation”, Canadian Journal of Economics, 33(3).

-Lane, T. (1993): “Market Discipline”, IMF Staff Papers, 40(1).

-Máiz, R.; Beramendi, P. and Grau, M. (2002): "La federalización del Estado de las Autonomías: evolución y déficit institucionales", en Subirats, J. and Gallego, R. (Eds.): Veinte años de autonomías en España. Leyes, políticas públicas, instituciones y opinión pública, Madrid: CIS, 379-424.

-McCarten, W.J. (2003): "The Challenge of Fiscal Discipline in the Indian States" in Rodden, J.; Eskeland, G.S. and Litvack, J.I. (Eds.): Fiscal Decentralization and the Challenge of Hard Budget Constraints, Cambridge, Mass: MIT Press.

-MEH (varios años): Liquidación de presupuestos de las Comunidades Autónomas, Madrid: Ministerio de Economía y Hacienda.

-Monasterio, C. and Suárez-Pandiello, J. (1998): Manual de hacienda autonómica y local, Barcelona: Ariel. 
-Monasterio, C. and Suárez-Pandiello, J. (2002): "Local Government Financing and Borrowing: Spain", in Dafflon, B. (Ed.): Local Public Finance in Europe, Cheltenham: Edward Elgar.

-Monasterio, C.; Sánchez I. and Blanco, F. (1999): Controles internos del endeudamiento versus racionamiento del crédito. Estudio especial del caso de las Comunidades Autónomas españolas, (Bilbao, Fundación BBV).

-Nicolini, J.P.; Posadas, J.; Sanguinetti, J.; Sanguinetti, P. and Tomassi, M. (2002): "Decentralization, Fiscal Discipline and the Bailout Problem: The Case of Argentina", Inter-American Development Bank, Research Network Working Paper, R-467.

-Pisauro, G. (2001): “Intergovernmental Relations and Fiscal Discipline: Between Commons and Soft Budget Constraints", IMF Working Paper, WP/01/65.

-Qian, Y. and Roland, G. (1998): "Federalism and the Soft Budget Constraint ", American Economic Review, 88(5).

-Qian, Y. and Weingast, B.R. (1997): "Federalism as a Commitment to Preserving Market Incentives", Journal of Economic Perspectives, 11(4).

-Rodden, J. (2002): “The Dilemma of Fiscal Federalism: Grants and Fiscal Performance around the World", American political Science Review, 46(3).

-Rodden, J.; Eskeland, G.S. and Litvack, J.I. (2003): "Introduction and Overview" in Rodden, J.; Eskeland, G.S. and Litvack, J.I. (Eds.): Fiscal Decentralization and the Challenge of Hard Budget Constraints, Cambridge, Mass: MIT Press.

-Rodden, J. and Eskeland, G.S. (2003): "Lessons and Conclusions" in Rodden, J.; Eskeland, G.S. and Litvack, J.I. (Eds.): Fiscal Decentralization and the Challenge of Hard Budget Constraints, Cambridge, Mass: MIT Press.

-Samuels, D. and Snyder, R. (2001): “The Value of a Vote: Malapportionment in Comparative Perspective", British Journal of Political Science, 31.

-Seitz, H. (2000): “Subnational Governments Bailouts in Germany”, Inter-American Development Bank, Research Network Working Paper, R-396.

-Utrilla, A. (2002): “Los efectos del nuevo sistema de financiación autonómica sobre la suficiencia y la equidad”, in Salinas, J. (Ed.): El nuevo modelo de financiación autonómica (2002), Madrid: IEF.

-Vallés, J. (2002): “La coordinación de las políticas de endeudamiento autonómico: una aproximación a los factores explicativos de los Escenarios de Consolidación Presupuestaria", Estudios sobre la Economía Española, EEE125, FEDEA, (http://www.fedea.es/hojas/publicado.html). 
-Von Hagen, J.; Bordignon, M.; Dahlberg, M.; Petterson, P. and Seitz, H. (2000): "Subnational Governments Bailouts in OECD Countries: Four Case Studies", InterAmerican Development Bank, Research Network Working Paper, R-399.

-Von Hagen, J. and Eichengreen, B. (1996): "Federalism, Fiscal Restraint, and European Monetary Union”, American Economic Review, 86(2).

-Wildasin, D (1997): “Externalities and Bailouts: Hard and Soft Budget Constraints in Intergovernmental Fiscal Relations", (http://econwpa.wustl.edu/eps/pe/papers/0112/0112002.pdf). 